\title{
SHOULD LABOUR SUPPORT INCREASING PRODUCTIVITY TECHNOLOGY?
}

\author{
Oladayo Nathaniel Awojobi \\ University of Siegen, Road to Democracy, Germany \\ dawojobi@gmail.com
}

\begin{abstract}
The interface between technology and employment is a complex one and has long been a contentious issue in economic theory. Moving to the classical question does technology create or dismantles jobs? Empirical studies have investigated the effect of various types of innovations and the structural and institutional factors affecting the quantity of employment change. Quality standings have received accumulating alertness, with the question of what brand of work is created or destroyed by new technology? This paper examines the increasing productivity technology as it relates to employment, workers' skills and productivity. From empirical evidence, the paper found that an innovation might affect employment in the short run, but in the long run it will increase employment, workers' skills and the standard of living. Furthermore, the paper sought for the cooperation of trade unions in the introducing of new technology by firms. This paper is based on a desk and literature review. Finally, it recommends the way forward for both trade unions and companies' management with the introduction of new technology in order to avoid conflict.
\end{abstract}

Keywords: Employment, Labour, Productivity Technology, Technological Change, Trade Unions 


\section{INTRODUCTION}

The relationship between increasing productivity technology and employment is a complex one and has long been a topical issue in economic theory (Pianta 2003). The contending question is, does technology create or destroys jobs? The impact of technology on employment is not straightforward, for a very long time, technology has been seen as a threat to employment, this is when a new technology may have led to the substitution of labour for capital. For some time now, the discussion on the interface between technology and employment has become more sophisticated, taking into cognizance how various types of increasing productivity technology under various market conditions, may have some impact on employment and employment composition, for example, process innovation can lead to substitution of labour for capital, but it can also increase productivity, increase demand, lower price, leading therefore to higher employment (Castillo et al. 2011, pp 1).

Productivity technology can also affect the skill composition of the labour force. New products and new processes may require specific skills which are not always available in the industry. This can lead to changes in the skill composition, either through training or through the hiring of more skilled workers, which at the same time are likely to be revealed by an increase in the average wage paid by technology firms. (Castillo et al. 2011, pp 2). Innovation is likely considered to be a primary source of economic growth, and policies to encourage firms to innovate are high in many countries. The results of increasing productivity technology for employment are of important interest, the long run economic effect of increasing productivity technology on employment is clearly not negative, many years ago, increasing productivity technology in advance economics has been accompanied by employment growth instead of the ever decreasing levels of jobs that may be predicted (Harrison et al. 2008).

A number of previous studies have provided evidence on the interrelationship between new technology and employment at the firm level. In all these studies, product increasing technology emerges as clearly associated with employment growth (Entorf and Pohlmeier 1991; Konig et al. 1995, Van Reenan 1997). Technological change brings benefit to all members of society. Consumers have choices to make when products are made possible by new technology, and thereby improving the standard of living through increased output per unit of labour input (Allan, 1991). Furthermore, technological change that leads to price reductions and improved international competitiveness will increase income and employment both in the short and the long run. Technological change is good for everybody in the long run, but there can be also short run adjustment problems. Change in technology can bring about temporary unemployment, premature retirement or permanent income loss for the workers. The loss of employment and tax can have serious consequences for particular communities while 
technological gains are distributed throughout the economy (ibid.). There are both social benefits and social costs imposed by technological change, some workers are made to pay for the cost of disengagement so that others can enjoy the gains of technological change. For this reason, there is a need for policy intervention to address the negative impact of technology change on employment.

The fear of organized labour is that increasing productivity technology may lead to unemployment, in assessing policies for convincing trade unions, why they should support increasing productivity technology, this paper identifies three factors that show the positive impact of productivity technology and its benefits to organized labour. These are the impact of productivity technology on employment, the impact of productivity technology on workers' skill and the impact of productivity technology on productivity. Each of these three factors mentioned above has a direct impact on employment and the society and they will be discussed in the subsequent section of this paper.

\section{PRODUCTIVITY TECHNOLOGY AND UNEMPLOYMENT: A Classical Debate}

With the coming of the industrial revolution, the extensive substitution of labour by machinery incorporating the new technology of the time has led economists and policy makers to debate the economic and social consequences (Pianta 2003). James Steuart drew attention to the difficulty of reabsorbing the unemployed caused by technology, in spite of the positive effects from construction of new machines and price reductions. Adam Smith linked the invention of machines to the division of labour and emphasized its labour saving effects. Thomas Malthus emphasized on the positive effects resulted from the strong demand dynamics experienced in England at the time. The optimism of the Classical economists in some years back contrasted with the dramatic improvement of the English working class, industrial workers, small artisans who had started to organize trade unions and launch the Luddite struggle against job losses and de-skilling brought by mechanization. David Ricardo, according to Piana (2003) was convinced that the economy could compensate the negative employment effects.

The most articulated criticism of 'compensation theory' was developed by Karl Marx, who emphasized the workers will lose in terms of jobs, skills, wages and control of their work resulting from the way mechanization was processed at that time. Karl Marx argued that unemployment increases as technology change displaces labour faster that the accumulation of capital demands new workers, Marx developed an insight on the functioning of capitalism. The drive to capital accumulation led to a constant search for new production methods and new products ((Pianta, 2003). Proponents of the structural unemployment concept argued that reducing unemployment will not be enough to address the issue of those that are affected by 
technological change and that more programmes are needed to address the mismatch between existing job vacancies and those that are out of the labour force which for one reason or the other, are unable to take advantage of them. However, the debate soon developed as more economists argued that the problem was slow growth and not technological change and that monetary and fiscal policies that lowered aggregate unemployment by stimulating demand would be sufficient to re-absorb the less-skilled and other disadvantaged workers (Woirol 1996).

Former President Lyndon Johnson of United States in 1965, appointed a National Commission on Technology, Automation, and Economic Progress and the commission found that the main cause of the high-unemployment rate was slow economic growth and not technological change. But when the report was issued economic growth had resumed in earnest. By 1965, when government cut taxes and spending led to a decline in unemployment, which made academic concern with automation and structural unemployment largely evaporated, repeating the experience of the great depression and World War II period (Woirol 1996, pp 111, 172). A national strike was averted in the United States in 1963 after complaints by owners of industries that unions were featherbedding by requiring that crews continue to use firemen to stock boiler even after the switch from steam to diesel. In 1964, the New York longshoremen's union won a guaranteed income for senior members over the effect of cargo containerization and mechanization on labour's demand (Woirol 19996, pp. 84, 95 and 100, Bix 2000). When John F. Kennedy ran in the presidential race of the United States, one of his aims was to revitalize the economy and he gave the issue prominence. He created the Office of Automation and Manpower in the Labour Department in 1961, and appointed a high-level commission to examine the issue and enacted an educational programme for displaced workers, the 1962 Manpower Development and Training Act (Woirol 1996, pp 77, and Bix 2000). Kennedy in 1962 identified "the major challenge facing workers when technology was replacing men" (Woirol 1996, pp 96).

The introduction of direct-dial service in the service sector for local telephone calls reduced the need for the vast number of operators to perform switchboard connections. However, there was a dramatic expansion of service meant for workers in the telephone company. A study by the Unites States Labour Department in 1955 showed that computers allowed an insurance company to reduce its clerical workers from 198 to 85, but some of these workers were redeployed to other departments. Similarly, when the Bank of America introduced magnetic ink character which can make it possible for machines to sort checks, track transactions and the print statement with 9 operators instead of 50 bookkeepers, with the coming of other scanning technology the Bank of America knew the consequence of introducing new technology and allow existing workers to be transferred to other departments (Bix 2000). 
With a deep recession in the early 1980s, and with the concern of the effect of new technology in the United States, a joint committee of the National Academy of Science, National Academy of Engineering and the Institute of Medicine created a Panel of Technology and Employment. According to Cyert and Mowery (1987), the panel x-rayed the impacts of new technology on overall employment level, job displacements, the occupational distribution of employment, skills, wages and the emerging training and education requirement. The panel finding was that the technology was a major contribution to job loss, the panel also noted the fears of the effects of technology during the Depression and the late 1959s and early 1960s period how they faded when full employment returned. In previous debates, there has been a strong tendency to confuse technological displacement with weakness in overall demand, which is known to affect less-skilled workers. New technology controversies and unemployment rates that have occasioned them to fade from view considerably when growth returned to normal. Technology is only one factor affecting employment and labour market among other factors and it is not all obvious that it is as significant as macroeconomic conditions. However, this does not negate the hardship being experienced by those that are adversely affected by structural change of the economy (Handel pp 8, 2000).

The first modern debate over the impact of new technology occurred before the Great Depression. In 1926-1927, the first-government productivity data on firm showed a rapid gain and declining employment in certain industrial sectors. The recession of 1927 showed concern on the media about the link between increased productivity and reduction in employment, but the Depression greatly magnified such concerns (Woirol 1996, pp 23). Economists carried out case studies of industries to understand the fates of workers displaced by new technology and the income loss for affected workers, but the data did not permit generalizing from the cases to the economy as a whole (Woirol pp 30 and 40). Some other economists performed simple statistical comparisons of trend in employment, output and productivity in different manufacturing industries to look if there was a link between improvements in efficiency and reduction in employment. Furthermore, economic theory suggested that the technology can bring efficiencies when new technology generates demand to reemploy those displaced by the new technology, but economists agreed that data and methodological limitation are made impossible any understanding of the extent to which technology can produce any ever-growing pool of continuous unemployment (Woirol 1996, pp 47, 75). Popular concern in early 1960s help prompted government inquiries and debates of professionals. However, most economists believed that the problem of technology-induced unemployment had been overstated in both cases, although other economists took an opposite view (Woirol 1996, pp 8). 
According to Woirol and Bix (1996/2000), the enthusiasm that surrounds new technology are to be taken to be hyperbolic by some views, but others were concerned about the technological displacement and disengagement of workers leading to the United States Congress to hold a hearing on the subject matter in the 1950s. The concern for labour leaders was that whether growth could keep pace with technological advances to ensure the reemployment of displaced workers and whether older workers could be retained. But owners of firms argued that the increase in efficiency would generate growth enough to absorb any employees whose jobs were eliminated and that the technology itself would require more highly skilled maintenance workers and create new occupations such as computer programmers and technicians. The labour statistics in the United States conducted case studies of new technology effects in some offices and firms, the resumption of output and employment growth caused this debate to be less heated than similar debates during the Great Depression (Woirol 1996 and Bix 2000).

\section{UNIONS AND BARGAINING}

According to Blechinger (et al. 1997), strongly unionized labour markets are sometimes blamed for Europe's delay of introducing productive technology when compared with the United States and Japan. Unions try to hinder new technologies with a negative effect on employment. This in turns reduces industries' incentive to invest in increase productivity technology. However, since there are many leading circumstances leading to a rise in employment and wages due to technological progress, unions' attitude toward technological progress are not as clear cut as this argument suggests. Rational unions will anticipate industries' investment reactions and take in to record the indirect impact on employment stemming from too little investment in increasing productivity technology in the future (Ramser, 1992). When industries and unions bargain, then the type of bargaining, the relative strength of unions and the objectives of unions will have an influence on the impact of increasing productivity technology on employment (Grout, 1984). Strong unions can prevent new technology in every industry. If unions are weak, industries will immediately adopt the process of introducing increasing productivity technology. Therefore, unions might have some incentives to prevent innovation. However, the result will depend on the structure of the bargaining, on the structure of the market and how much weight unions can put on employment and wages. Industries usually have the prerogative to decide what technology to introduce and when to adopt it, the purpose of the technology change and what it is to use for and who shall use it. Negotiations with trade unions always happen after these decisions have already been made. Unions can be involved in the negotiations of the introduction of new technology, but that cannot change the choice of the technology that is being introduced. Unions have no choice when new technology is introduced, but to embrace it 
because resistance might be useless. On the other hand, if there is no formal negotiation, it is possible that union preference might shape management preferences. This would make it difficult to economically identify the impact of the unions (Doucouliagos and Laroche 2012).

\section{Union Condition for Cooperation}

For technological changes to take place in a firm, there is a tendency for the union to cooperate with the management of the firm with the introduction of technological changes, Peitchinis in his article gave union conditions for their cooperation. According to Peitchinis (1983) technological changes are regarded as managerial prerogative, where the labour-management environment appears very conducive for the introduction of contractual provisions which will help reduce any negative effect on workers. Among the provisions sought by unions the important ones are:

(a) Notice in advance of a change in technology

(b) Labour and management discussions regarding time, procedures and accommodation of affected workers.

(c) Guarantee that permanent workers will not lose their jobs as a result of technological changes.

(d) Commitment by employers that necessary reductions in employment will be achieved through attrition, at some agreed annual rate.

(e) Separation allowances for workers who decided to retire.

However, a collective agreement with unions reveals a significant gap between what unions have sought and what they have obtained. Management continues to regard technological change a managerial prerogative. The responses indicate that approximately $(53 \%$ of the respondents had negotiated advance notice to the union of pending changes, the period of advance between 90 days (35\% of respondents) and 60 days (8.2\% of respondents), $8.2 \%$ had negotiated as much as possible advance notice, $2 \%$ negotiated 4 months, and one indicated one year's notice. Although the majority of respondents indicated that their primary goal was to ensure the employment of their members, only 36\% appear to have succeeded in the negotiation of retraining, and only three indicated that they had negotiated guaranteed employment, $27 \%$ had negotiated severance pay and $23 \%$ had provisions for early retirement.

\section{WHY UNION SHOULD SUPPORT INCREASING PRODUCTIVITY TECHNOLOGY Impact of Increasing Productivity Technology on Employment}

Industries where productivity technology is introduced, it shows the direct impact on employment. A number of studies have explored the issue with a variety of models, national 
studies, and panel of firms (Petit 1995; Channells and Van Reenen 1999; Spiezia and Vivarelli 2002). The evidence on the overall employment impact of productivity technology of industries tends to be positive, industries that introduce new technology in products, and also in processes, grow faster and are more likely to expand their employment than industries that did not introduce productivity technology on their products regardless of the industry, size, or other characteristics (Reenen 1997). The variety of technology strategies, job creation, and destruction patterns have been highlighted in such studies, together with industries' characteristics. Some studies have also suggested that the positive impacts of technological innovation are linked to organizational changes. A study of a large sample of firms in France found that firms that adopted advanced manufacturing in the period of 1988-93 and introduced in parallel organizational change had greater employment growth than others, regardless of size or sector and that this positive effect was greater than in firms that introduced organizational innovations only (Greenan 2003).

Using the work of (Blechinger et al. 1996) on the impact of technology on employment in Europe, they found through the analysis of Konig, Buscher and Licht (1995) that productivity technology has a positive impact on an employment plan due to an increase in final demand in Germany in 1993. They used data obtained from the Mannheim Innovation Panel (MIP) and the Mannheim Enterprise Panel (MUP), where a broad range of topics related to the entire technology process within firms interviewed was included. Reported demand expectations are the most important factors for future employment plans has been confirmed in earlier work for German firms in the period from 1981 to 1984 (Zimmermann, 1987). Evidence from the United States suggests that industries using advanced technology pay higher wages offer more jobs and increase employment more rapidly than other plans. Technology is found to contribute to the creation of quality jobs. Industries with advanced technology hire workers with higher skills and pay them better wages. At the industry level, there is a positive relationship between technology and employment (Christidis et al. 2002) From the analysis above one could see that productivity increasing technology has much more positive impact on employment than the negative impact, with this, labour should think of supporting innovation in industries since it will be of benefit to workers.

\section{Impact of Increasing Productivity Technology on Workers' Skills}

Skilled work has increased in the past decades, rooted in the changes in economic structures, technologies and in the growing availability of educated workers. Many studies mainly in advanced countries' firms argued that in the last twenty years, this process has accelerated, as a result of the introduction of information technology and computer. The issue, according to 
(Pianta (2003), has been generally been investigated using a factor substitution framework, showing that direct or indirect measure of technology is important explanatory factors for the relative increase of skilled labour (Doms et al. 1997).

A study from United States on the industry level, which was carried out by Berman, Bound and Griliches in 1984, using R\&D expenditures and computer investment as their measures of technical change. These technological proxies are found to have a positive and significant impact on workers' skills, the computer variable accounting for about a third of the increase of skill of workers. Autor, Katz and Krueger (1998) extended this study over a longer period, from 1940s to 1990 , and to non-manufacturing. They corroborated the significance of technical change, especially computer use in accounting for the increase in skilled workers as a proportion of the wage bill. Machin and Van Reenen (1998), extended the United States results to the manufacturing sectors of other advanced countries such as Denmark, Germany, France, Japan, Sweden and the UK. Both results broadly support the importance of skill bias across all countries using their measure of Research and Development (R\&D) intensity. Adams (1999) focuses on firms mainly operating in the chemical industries. In his careful study, he found that firm in R\&D in the same product field as that produced the plant is associated with skilled bias. Channells and Van Reenen (1999) used a technology survey to estimate the cost share equation for a panel of French manufacturing firms in 1986-1991 in long differences. They found evidence for skill bias and argued that it comes primarily from the introduction of new products. Over the years the demand for skilled labour seems to have increased in Europe as a much faster rate than its supply, as a result, skilled workers find employment more easily and are well paid than the unskilled (Nickell and Bell 1995).

\section{The Impact of Increasing Productivity Technology on Productivity}

As labour productivity is a major determinant of the economic well-being of people, it is important to know if any policy instrument can lead to the improvements in productivity. Studies have shown that labour productivity is influenced by such factors as the openness of nations to competition, training, education, investment in production capital and technology. In some years back, an important insight into factors affecting productivity growth have been achieved as a result of an approach known as economics of technological change (Dosi et al. 1988). Technological change brings about an increase in productivity which lower prices of goods, thereby given improving the living standard of consumers. 


\section{RECOMMENDATIONS}

The followings are recommended to prevent conflict between labour and companies' management over the introduction of new productivity technology:

1. Encouraging Labour-Management Cooperation: A holistic programme to encourage labourmanagement's mutual cooperation is needed in order to avoid conflict when a new technology is being introduced.

2. Collective Bargaining Law: Where the current policy interferes with the cooperation, it should be changed. Plant introducing technology should be made a mandatory subject for bargaining to encourage the exchange of information and the recognition of mutual interest between management and labour.

3. Full Employment Policy: The most important factor in achieving rapid redeployment of human resources after dislocation of structural change is adequate labour demand.

4. Information Needs: There is an appropriate public role in providing the information needed by private decision makers in choosing careers, searching for works and seeking training opportunity.

5. Appropriate Educational Strategies: A clear determination should be made for an educational requirement for labour market entry. Concentration should be on basic skills of reasoning, problem solving, and communication is needed for general high school graduate.

6. The productivity and jobs gain linked to new technologies are best realized when firms make complementary investments in organizational change and up-skilling. Countries like Canada, the United States and United Kingdom have improved previously uneven in this respect.

7. Unions should be notified by the company as soon any new technology will affect working conditions, salaries, manpower levels. With regard to such technology, the company should provide information such as: Manufacturers' specifications, Sales brochures, Implementation plan.

8. Union officials should be provided with paid time off to attend courses, seminars and conference in order to equip them better to negotiate technological change.

9. New technology should not be introduced until full agreement has been reached with the union on a whole range of negotiating issues.

10. Staffing levels for new equipment must be provided so that social, health and safety problem will not be increased.

11. On approval for new technology, firms should allow union sufficient time to research and prepare a presentation which will consider such items as health, working conditions, safety and other possible social problems. 


\section{CONCLUSION}

The study examines the linkage between increasing productivity technology and employment. From available data, new technology can reduce employment in the short run, but in the long run, employment will increase. Further to this, the paper sought for the indulgence of the trade unions to support the introduction of new technology at the work places because of the positive impacts of increasing technology on employment, workers' skills and productivity.

\section{REFERENCES}

Adams, J.D. (1999) 'The Structure of Firm R\&D, the Factor Intensity of Production and Skill Bias', Review of Economics and Statistics, vol. 81, pp. 499-501

Allan H.A. (1991) "Human Resource Policy Issues: Panel on Technology and Employment, Committee on Science, Engineering, and Public Policy." For the National Academy of Sciences, Committee on Science, Engineering, and Public Policy, Panel on Technology and Employment. pp 1-5

Bix, A.S. (2000) Inventing Ourselves Out of a Job? America's Debate over Technological Unemployment, 1929-1981. Baltimore: Johns Hopkins University Press. pp 242-243, 258-259, 275

Blechinger, D., Kleinknecht, A., Licht G., Pfeiffer, F. (2006) The impact of innovation on employment in Europe, Zentrum fur Europeaische Wirtschaftsforschung (ZEW), Delft University of Technology (TU Gelft), NL. EIMS Publication No. 46. pp 16, 20

Castillo, V., Maffioli, Rojo, S. \& Stucchi, R. (2011), Innovation policy and employment, Evidence from and evaluation in Argentina

Cyert, R.M. \& Mowery, D.C. (1987) Technology and Employment: Innovation and Growth in the U.S. Economy. Washington, DC: National Academy Press. Pp 87, 209

Chennells, L. \& Van Reenen, J. (1999) Has technology hurt less skilled workers? An econometric survey of the effects of technical change on the structure of pay and jobs. Institute for Fiscal Studies working paper 27, London

Christidis, P., Hernandez, Lievonen J (2002) Change on employment: Prospect analysis 2020, Study for the committee of employment and social affairs of the European Parliament, IPTS-ESTO pp 31-32

Doms, M., T. Dunne, and Troske. K. (1997) 'Workers, Wages and Technology', Quarterly Journal of Economics, vol. 112, pp. 253-290.

Dosi, G., C. Freeman, R., Nelson, G., Silverberg, \& Soete, L. (1988) Technical change and economic theory. Pinter, London.

Doucouliagos, H. \& Laroche, P. (2012) Unions, innovation, and technology adoption: New insights from the cross-country evidence, School of Accounting, Economics and Finance, Deakin University, Melbourne pp 2, 4

Entorf, H. \& Pohlmeir, W. (1990) Employment, innovation and export activity, in Florens, J. et al. (eds) Microeconometrics: surveys and applications. Oxford, Basil Blackwell.

Grout, P.A. (1984) "Investment and Wages in the Absence of Binding Contracts: A Nash Bargaining Approach", Econometrica, Vol. 52, \# 2.

Greenan, N. (2003) Organisational change, technology, employment and skills: an empirical study of French manufacturing. Cambridge Journal of Economics, 27:287-316.

Grout, P.A. (1984) "Investment and Wages in the Absence of Binding Contracts: A Nash Bargaining Approach", Econometrica, Vol. 52, \# 2.

Handel, M.J. (2000) Models of Economic Organization and the New Inequality in the United States. Ph.D. diss., Harvard University. 
Harrison, R., Jaumandreu., J, Mairesse, P.B. (2008) Does innovation stimulate growth? A firm level analysis using comparative micro data from four European countries

Konig, H., Buscher, H. \& Licht, G. (1995) "Employment, Investment and Innovation at the Firm Level", Chapter 2 in: The OECD Jobs Study, OECD, Paris

Nickell, S. \& Bell, B. (1995) 'The Collapse in Demand for the Unskilled and Unemployment across the OECD', Oxford Review of Economic Policy, vol.11, pp. 40

Petit, P. (1995) Employment and Technological Change, in Stoneman, P. (ed), Handbook of the Economics of Innovation and Technological Change, Amsterdam, North Holland, pp 366

Ramser, H.J. (1992) "Gewerkschaftspolitik, Arbeitslosigkeit und technologischer Wandel",in: W. Franz (Hrsg) Mikro- und makrookonomische Aspekte der Arbeitslosigkeit, Beitrage zur Arbeitsmarkt- und Berufsforschung, Niirnberg.

Spezia, V. \& Vivarelli, M. (2002) Innovation and employment: a critical survey. In N. Greenan, Y. L'Horty and J. Mairesse (eds), 101-105

Van Reenen, J. (1997) Employment and Technological Innovation: Evidence from U.K. Manufacturing Firms, Journal of Labor Economics, vol. 15, 255-84

Woirol, G.R. (1996) The Technological Unemployment and Structural Unemployment Debates. Westport, CT: Greenwood Press.

Zimmerman, K.F. (1987) Innovation und Beschaftigung", in Arbeitsmarkte und Beschaftigung-Fakten, Analysen, Perspektiven, in: G. Bombach (ed.), Tubingen, 1987. 